\title{
TRADISI MERASI DALAM ADAT PERKAWINAN MELAYU RIAU: STUDI ANALISIS TERHADAP PENENTUAN KAFAAH CALON PENGANTIN DI KELURAHAN BAGAN BATU
}

\author{
Rahmat Pulungan \\ Pascasarjana Prodi Hukum Islam IAIN Bukittinggi \\ e-mail: rabmat_pulungan@yahoo.co.id \\ DOI: bttp://dx.doi.org/10.30983/islam_realitas.v2i2.188
}

Diterima: 2 Oktober $2016 \quad$ Direvisi : 12 November $2016 \quad$ Diterbitkan: 20 Desember 2016

\begin{abstract}
Kafaah aims to create harmony and balance in marriage. The criteria of kafaah in jurisprudence according to scholarly are nasab, wealth, beauty, diyanah, birfah and self independence. The problem that occurs is when determining kafaah in Bagan Batu, the Malay community has its own way in the process or determine kafaab; they carry the tradition called merasi to ensure compatibility between their children who will carry out the marriage. The main problem to be answered through this research is to determine how the process of merasi in determinig kafaah conducted by Malay community in Bagan Batu, what is the purpose of this tradition and how the views of Islamic law against the tradition. The purpose of this study: 1). To know the procedures of merasi tradition 2). To find out the purpose of merasi in determining kafaah 3). To find out the views of the Islamic law in the determination of kafaah through merasi process undertaken by the community of Bagan Batu, Bagan Sinembah, Riau Province. The research is a field research that is descriptive qualitative. In the collection of necessary data, the author uses interview and observation techniques. While in the data analysis techniques, used qualitative method that describes the situation on the ground systematically. The results of this research is merasi tradition that conducted by people in Bagan Batu by combining both the name of the bride, and the progenitor will predict the state of their household after marriage. The way of this merasi may vary according to the progenitor who will perform it. Whereas the purpose of this merasi to reduce the disadvantages and for the achievement of the benefit in marriage. Merasi tradition in determining kafaah that happened inBagan Batu may be accepted and enforced. Because, during the process nothing contrary to Islamic law, also aimed to benefit of the people. In fact, before merasi the progenitor will ask the religious understanding of the bride, and it is also used as a basic foundation for determining the kafaab between the couple
\end{abstract}

Keywords: Kafaah, Merasi, Marriage Tradition

\begin{abstract}
Abstrak
Kafaah bertujuan untuk menciptakan keserasian dan keseimbangan dalam perkawinan. Kriteria kafaab dalam fikih menurut jumhur ulama ialah nasab, kekayaan, kecantikan, diyanah, birfah, dan kemerdekaan diri. Permasalahan yang terjadi adalah saat menentukan kafaah, di Kel. Bagan Batu, para masyarakat Melayu mempunyai proses atau cara tersendiri dalam menentukan kafaah, mereka melaksanakan tradisi merasi untuk memastikan keserasian antara anak mereka yang akan melaksanakan perkawinan. Masalah penelitian ini adalah bagaimana proses merasi dalam menentukan kafaah yang dilakukan masyarakat Melayu di Kel. Bagan Batu, apa tujuan dari tradisi merasi dan bagaimana pandangan hukum Islam terhadap tradisi merasi tersebut. Riau. proses merasi yang dilakukan masyarakat Bagan Batu yaitu dengan cara menggabungkan kedua nama calon mempelai, dan datuk yang bersangkutan akan meramal keadaan rumah tangga mereka setelah menikah. Cara merasi ini beragam metodenya sesuai dengan datuk yang akan mem-faal. Sedangkantujuan dari merasi ini untuk mengurangi kemudharatan dan demi tercapainya kemaslahatan dalam pernikahan. Tradisi merasi dalam penentuan kafaah yang terjadi di Kel. Bagan Batu ini boleh diterima dan diberlakukan.
\end{abstract}


Karena, selama proses merasi tidak ada hal yang bertentangan dengan hukum Islam yang juga menginginkan kemaslahatan umat. Bahkan, sebelum merasi para datuk akan menanyakan pemahaman agama para calon pengantin, dan hal ini juga dijadikan sebagai landasan dasar dalam menentukan kafaah antara pasangan tersebut.

Kata Kunci: Kafaah, Merasi, Adat Perkawinan

\section{Latar Belakang}

Kehidupan dunia yang sangat singkat ini adalah tempat bersusah payah dan bersenangsenang sesaat bagi manusia. Kesenangan dan ketenangan merupakan sesuatu yang sangat diinginkan oleh setiap insan dan merupakan fitrah bagi manusia untuk memperolehnya, sehingga dia cenderung ke arah itu. Di antara kesenangan itu adalah perkawinan atau rumah tangga. Jika ada surga di dunia maka surga itu adalah pernikahan atau rumah tangga. Sebaliknya, bila ada neraka di dunia, maka itu adalah rumah tangga yang penuh dengan persoalan dan pertengkaran antara suami dan isteri $^{1}$.

Salah satu tujuan dari pernikahan untuk membentuk rumah tangga yang Islami, rumah tangga yang berjalan sesuai dengan koridor agama Islam. Hal ini tidak akan terwujud, jika seseorang pria salah memilih pasangan atau belum sepenuhnya mengetahui kepribadian pasangan yang hendak di nikahinya. Oleh karena itu seorang pria harus mengetahui dan mengenal pasangannya sebelum menikah, agar tidak terjadi kesalahpahaman dan perselisihan di kemudian hari yang akhirnya berujung pada pertengkaran dan perceraian yang tidak sesuai dengan hikmah pernikahan itu sendiri. ${ }^{2}$

Kafaah (kufu) ialah sama atau setara. Kata "kafaah" dalam perkawinan mengandung arti bahwa perempuan harus sama atau setara

${ }^{1}$ Lubis Salam, Menuju Keluarga Sakinah (Surabaya: Salam, 2003), h. 5.

${ }^{2}$ Fuad Kauma dan Nipan, Membingbing Isteri Mendampingi Suami (Yogyakarta: Mitra Pustaka, 2003), h. 8. dengan laki-laki. Sifat kafaah mengandung arti sifat yang terdapat pada perempuan yang dalam perkawinan, sifat tersebut diperhitungkan harus ada pada laki-laki yang mengawininya. ${ }^{3}$

Standar dalam penentuan kafaab itu adalah status sosial pihak perempuan, karena dialah yang akan dipinang oleh laki-laki untuk dikawini. Laki-laki yang mengawininya paling tidak harus sama dengan perempuan, jika lebih tidak menjadi halangan.Seandainya pihak istri dapat menerima kekurangan laki-laki tidak menjadi masalah. Masalah timbul kalau lakilaki yang kurang status sosialnya sehingga dikatakan si laki-laki tidak sekafaah dengan istri. Inilah yang menjadi ukuran kafaah di kalangan ulama fikih. ${ }^{4}$

Peminangan itu disyariatkan dalam suatu perkawinan, yang waktu pelaksanaannya diadakan sebelum berlangsungnya akad nikah. Keadaan ini pun sudah membudaya ditengah masyarakat dan dilaksanakan sesuai dengan tradisi masyarakat setempat. Dalam tradisi Islam sebagaimana tersebut dalam hadist $\mathrm{Nabi}$, yang mengajukan pinangan itu adalah dari pihak laki-laki, boleh laki-laki itu sendiri yang datang untuk menyampaikan pinangannya atau mengutus perempuan yang dipercaya untuk melakukannya, sedangkan pihak perempuan berada dalam status orang yang menerima pinangan. Dalam hukum Islam tidak dijelaskan tentang cara-cara pinangan secara jelas. Hal itu

\footnotetext{
${ }^{3}$ Amir Syarifuddin, Hukum Perkawinan Islam di Indonesia (Jakarta: Kencana, 2007), h.140

4 Amir Syarifuddin, Hukum Perkawinan Islam di Indonesia..., h. 141.
} 
memberikan peluang bagi kita untuk mengikuti adat istiadat yang berlaku. ${ }^{5}$

Lain halnya dengan masyarakat suku Melayu yang ada di Kel. Bagan Batu Kec. Bagan Sinembah Kab.Rokan Hilir Prov.Riau. Untuk menikah mereka harus melalui beberapa proses adat, seperti adat merisik kemudian dilanjutkan dengan merasi. Hal ini harus dipenuhi terlebih dahulu, setelah itu barulah mereka dapat melaksanakan peminangan dan akad nikah, karena pasangan yang telah lewat dari proses adat tersebut sudah dianggap pasangan yang cocok atau sekafaah.

Dalam Islam dasar keserasian pasangan (kafaah) sudah dijelaskan sedemikian rupa, diantaranya keduanya beraga Islam, memiliki rupa yang tampan dan cantik, keduanya dari keturunan yang baik, keduanya orang kaya, dan keduanya berpendidikan. ${ }^{6}$

Sedangkan masyarakat Melayu dalam Riva'ie, lebih berpegang teguh pada keputusan ramalan datuk mereka, sehingga jika datuk mengatakan pasangan serasi, mereka akan melangsungkan peminangan dan pernikahan. Apabila putusan dari ramalan pasangan tidak serasi, maka mereka akan membatalkan perjodohan anak mereka, padahal jika dipandang dari Syari'at Islam pasangan tersebut sudah memenuhi kriteria sekafaah?

Praktek proses peminangan dalam tradisi budaya lokal di Nusantarapun secara umum sebagaimana penelitian Muslim ${ }^{8}$, Novi

5 Mustofa Hasan, Pengantar Hukum Keluarga, (Bandung: CV Pustaka Setia, 2011), h. 70.

6 Beni Ahmad Saebani, Figh Munakahat 2 (Bandung: Pustaka Setia, 2001), h. 200

7 Riva'ie, Wanto, and Gusti Budjang, "Peran Tokoh Masyarakat Menanamkan Nilai-nilai Solidaritas dalam Tahapan Pesta Perkawinan Suku Melayu", Jurnal Pendidikan dan Pembelajaran, 5.06, 2015, h. 34

8 Muslim, Muslihun, and Muhammad Taisir, "Tradisi Merari': Analisis Hukum Islam dan Gender terhadap Adat Perkawinan Sasak", Yogyakarta: Kurnia Kalam Semesta, Vol. 12, No. 3, 2009, h. 23.
${ }^{9}$ dan Rachmadani ${ }^{10}$ untuk mencari keserasian pasangan semacam ini, berbeda dengan yang terdapat di dalam ayat dan hadist, begitu juga pada KHI pasal 61. Tidak sekufu tidak dapat dijadikan alasan untuk mencegah perkawinan, kecuali tidak sekufu karena perbedaan agama atau ikbtilafu al-din. Oleh karena itu tulisan ini ingin menjelaskan tentang tradisi merasi dalam adat perkawinan Melayu Riau, sebuah studi analisis terhadap penentuan kafaah calon pengantin di Kelurahan Bagan Batu.

\section{Kafaah dalam Teori Fikih}

Problematika utama pernikahan, kesulitan dan kehancurannya, bersumber dari sikap terburu-buru dalam memilih pasangan hidup tanpa meneliti dan menyelidikinya dengan seksama. Betapa banyak pemuda maupun pemudi dalam memilih pasangannya hanya didasarkan pada kecantikan semata yang membuat kepala terasa pusing dan tertimpa berbagai malapetaka. Hal serupa juga akan menimpa pemudi yang tergesa-gesa dalam memilih pasangan hidupnya. ${ }^{11}$

Pengertian kafaah menurut bahasa dari kata bahasa Arab yaitu كفئ, kata kafaah juga merupakan kata jamak dari kufu yang bermakna serupa, setara dan sepadan. ${ }^{12}$ Kata kafaah sinonim dengan al-mumasalab artinya sebanding atau seimbang. Sebanding atau seimbang antara calon suami dan isteri baik

9 Novia, Nila, and Swis Tantoro, "Perubahan adat perkawinan suku sakai di pemukiman buluh kasap kopelapip kecamatan Mandau", Jurnal Online Mahasiswa (JOM) Bidang Ilmu Sosial dan Ilmu Politik, 1.1, 2014, h. 112.

10 Rachmadani, Arnis, "Local Wisdom Tradisi Perkawinan Islam Wetu Telu sebagai Perekat Kerukunan Masyarakat Bayan", Dinamika Beragama dalam Pergumulan Sosial Budaya, Vol. 1, No. 2, 2015, h. 662.

${ }^{11}$ Mahmud Mahdi, Kelurga Sakinah (Jakarta: PT Sahara, 2013), h. 52. Lihat juga, Sobirin, Achmad, "Merger dan Akuisisi: Sebuah Perkawinan Paradoksal", Jurnal Siasat Bisnis 1.6, 2001, h. 20.

${ }^{12}$ Rusyadi, Kamus Arab-Indonesia (Jakarta: Bineka Cipta, 1995), h. 750. 
dari sudut agama, akhlak, kedudukan dan status sosial. ${ }^{13}$ Kata ini merupakan kata yang terdapat dalam Al- Qur'an dengan arti "sama" atau setara. Menurut Abu Luwis al- Ma'luf kafaah adalah suatu keadaan yang dengannya sesuatu menyamai yang lain ${ }^{14}$. Kata kafaah atau kufu dalam perkawinan mengandung arti bahwa perempuan harus sama atau setara dengan laki-laki. Sifat kafaah yang mengandung arti sifat yang terdapat pada perempuan yang dalam perkawinan sifat tersebut diperhitungkan harus ada pada laki-laki yang mengawininya. ${ }^{15}$

Kafaah dalam perkawinan menurut hukum Islam yaitu keseimbangan dan keserasian antara calon isteri dan suami, sehingga masing-masing calon tidak merasa berat untuk melangsungkan perkawinan atau laki-laki sebanding dengan calon isterinya, sama dalam kedudukan, sebanding dengan tingkat sosial dan sederajat dalam akhlak serta kekayaan.

Jadi, tekanan dalam kafaah adalah keseimbangan, keharmonisan dan keserasian, terutama dalam hal agama, yaitu akhlak dan ibadah. Sebab kalau kafaah diartikan persamaan dalam hal harta atau kebangsawanan, maka terbentuklah kasta sedangkan manusia disisi Allah SWT adalah sama. Karena hanya ketaqwaan manusia yang menjadi pembedanya. ${ }^{16}$

Dalam hal kedudukannya dalam perkawinan terdapat beda pendapat dikalangan ulama. Jumhur ulama termasuk Malikiyah, Syafi'iah, Hanafiyah (Ablu Ra'yl) dan satu riwayat dari Imam Ahmad berpendapat bahwa kafaah itu tidak termasuk syarat dalam

${ }^{13}$ Dahlan Idhami, Aras-Azas Fiqih Munakahat (Surabaya: Al-Ikhlas, 1991), h.18.

14 Abu Luwis, al-Ma'luf, Munjid (Bairut: Maktabah al-Katulikiyah Babil Halabi, 1997), h. 690.

${ }^{15}$ Amir Syarifuddin, Hukum Perkawinan Islam di Indonesia..., h. 40.

16 Abdur Rahman Ghazaly, Fiqh Munakahat (Jakarta: PT Grafindo Persada, 2003), h. 97. pernikahan, dalam arti kafaab itu hanya semata keutamaan dan sah pernikahan antara orang yang tidak se-kufu.

Sebagian ulama termasuk satu riwayat dari Ahmad mengatakan bahwa kafaab itu termasuk syarat sahnya perkawinan, artinya tidak sahnya perkawinan antara laki-laki dengan perempuan yang tidak se-kufu Begitu pula halnya dengan ulama Hanafiyah, Hanabilah dan Syafi'iah. Mereka mengakui adanya kafaah dengan dasar-dasar yang akan disampaikan nanti, meskipun kafaah masih dalam ruang lingkup keutamaan, bukan merupakan salah satu syarat yang menentukan keabsahan nikah.

Di antara ulama yang sepakat tentang ini, kebanyakannya tidak menempatkan kafaah sebagai syarat.Kafaah dalam hal ini hanyalah keutamaan bila dibandingkan dengan yang lain. Dalam mengambil menantu umpamanya bila berkompetinsi antara yang taat dengan yang biasa-biasa saja, maka harus didahulukan yang taat.

Jadi, ada dua pendapat tentang kafaah (keserasian) dalam perkawinan. Pertama, kafaah merupakan syarat sahnya perkawinan. Tidak sah perkawinan apabila laki-laki dan perempuan yang dinikahinya tidak se-kufu. Berdasarkan pendapat ini, bila terjadi pernikahan yang tidak ada kafaah di dalamnya, akad nikah tersebut batal. Kedua, kafaah bukan merupakan syarat sah pernikahan. Meski tidak se-kafaah, seseorang tetap dapat melangsungkan pernikahan dengan orang yang disukainya, akad mereka sah. Ini merupakan pendapat mayoritas ulama. ${ }^{17}$

Selain rukun-rukun nikah seperti, calon suami dan isteri, wali nikah, dua orang saksi dan ijab qabul. Ada perkara lain yang dituntut terhadap kedua mempelai yaitu harus kafaah

${ }^{17}$ Muhammad Fauzil Adhim dan M. Nazif Mansyur, Di Ambang Pernikahan (Jakarta: Gema Insani Pers, 2002), h.72 
atau sepadan. Meskipun bukan termasuk syarat, dianjurkan oleh Rasulullah SAW. Bahwa pasangan yang akan menikah hendaknya sepadan.

Kafaah ini tidak menjadi syarat bagi pernikahan. Akan tetapi, jika tidak dengan keridaan masing-masing, salah satu pihak boleh membatalkan pernikahan itu dengan alasan tidak sekafaah. ${ }^{18}$ Dalam hal kedudukan standar kafaah dalam perkawinan terdapat perbedaan pendapat dikalangan ulama. Perbedaan pendapat ini kata Ibnu Rusydi disebabkan adanya perbedaan pendapat tentang mafhum (pemahaman) ${ }^{19}$.Dari sabda Nabi SAW, yang berbunyi:

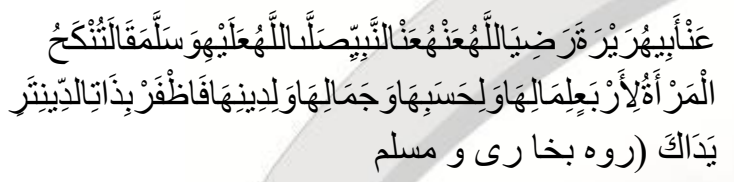

"Abu Hurairah meriwayatkan bahwa Nabi SAW bersabda,"Perempuan itu dinikahi karena empat faktor, yaitu karena hartanya, keturunannya, kecantikannya, dan agamanya. Pilihlah yang beragama engkau akan selamat"( H.R. Bukhari dan Muslim). ${ }^{r}$

Yang dimaksud dengan hadist nabi diatas, kafaah adalah keadaan suami-isteri yang memiliki kesamaan dalam beberapa hal, yaitu: keduanya orang kaya, keduanya dari keturunan yang baik, memiliki rupa yang tampan dan yang cantik, keduanya beragama Islam.

Dalam kriteria yang digunakan untuk menetukan kafaah, ulama berbeda pendapat yang secara lengkap tuliskan oleh Amir Syarifuddin di dalam bukunya Hukum perkawinan Islam di Indonesia yang diuraikan oleh Al- Jaziriy. Menurut ulama Malikiyah ini

\footnotetext{
${ }^{18}$ Mustafa Hasan, Pengantar Hukum Keluarga (Bandung: CV Pustaka Setia, 2011), h. 63.

${ }^{19}$ Tihami dan Sohari Sahrani, Fikih Munakahat (Jakarta: Raja Wali Pres, 2010 ), h. 59.

${ }^{20}$ Imam Abi Husain Muslim bin Hajjaj AlQusyairi An-Nasai, Shabiab Muslim (Indonesia: T,Th), juz V, h. 3450
}

yang menjadi kriteria kafaah hanyalah dinayah atau kualitas keberagamaan dan bebas dari cacat fisik.

Menurut ulama Syafi'iah yang menjadi kriteria kafaah itu adalah: a)Kebangsaan atau nasab; b)Kualitas keberagamaan; c)Kemerdekaaan diri; d) Usaha atau propesi. Sedangkan Menurut ulama Hanabillah yang menjadi kriteria kafaah itu adalah: a)Kualitas keberagamaan; b)Usaha atau propesi; c)Kekayaan; d)Kemerdekaan diri; e)Kebangsaan. ${ }^{21}$

Berbagai pendapat tentang aspek kafaah di atas perlu diperhitungkan dalam pernikahan. Muhammad Fauzil Admim dalam bukunya di ambang pernikahan, mengutip pendapat Abdullah Nashih Ulwan, yang berpendapat bahwa kesetaraan atau kafaah meliputi aspek agama, keturunan atau nasab, pekerjaan, kehormatan dan harta. Sementara itu, sebagian ulama berpendapat bahwa kafaah meliputi keturunan, agama, merdeka, pekerjaan, usia, dan terlepas dari empat aib yakni kusta, penyakit sopak, gila dan impoten. ${ }^{22}$

Semua fuqaha berpendapat adanya penolakan nikah karena adanya cacat, dan menganggap keselamatan cacat termasuk dalam lingkup kafaah. Di kalangan Maliki faktor kemiskinan dan kemerdekaan dari pihak laki-laki termasuk penyebab batalnya perkawinan dan termasuk dalam lingkup pengertian kafaah.

Dalam akad nikah ada empat macam syarat yaitu sebagai berikut:

Pertama, Syuruth al-in'iqad. Syarat akad adalah syarat yang menentukan terlaksananya suatu akad perkawinan. Karena kelangsungan perkawinan tergantung pada akad, maka syarat disini adalah syarat yang harus dipenuhi karena ia berkenaan dengan akad itu sendiri. Bila

\footnotetext{
${ }^{21}$ Amir Syarifuddin, Hukum Perkawinan Islam di Indonesia...., h.142.

${ }^{22}$ Muhammad Fauzil Adhim dan M. Nazif Mansyur, Di Ambang Pernikahan....., h.73.
} 
syarat-syarat itu tertinggal, maka akad perkawinan disepakati batal. Umpamanya, pihak-pihak yang melakukan akad adalah orang yang memiliki kemampuan untuk bertindak hukum.

Kedua, Syuruth al-shibhah. Syarat sah nikah adalah yang membuat akad itu patut menimbulkan beberapa hukum. Jika satu syarat saja tidak ada, maka akadnya rusak. Adapun syarat sah akad ada tiga: adanya persaksian, wanita yang akan dinikahi tidak haram untuk selamanya atau sementara bagi suami, dan shighat akad hendaknya untuk selamanya. $^{23}$

Ketiga, Syuruth al-nufur. Syarat yang menentukan kelangsungan suatu perkawinan. Akibat hukum setelah berlangsung dan sahnya perkawinan tergantung kepada adanya syaratsyarat itu tidak terpenuhi menyebabkan fasadnya perkawinan, seperti wali yang melangsungkan akad perkawinan adalah seseorang yang berwenang untuk itu.

Keempat, Syarat keharusan nikah. Syarat yang menentukan kepastian suatu perkawinan dalam arti tergantung kepadanya kelanjutan berlangsungnya suatu perkawinan sehingga dengan telah terdapatnya syarat tersebut tidak mungkin perkawinan yang sudah berlangsung itu dibatalkan, seperti suami harus sekufu dengan isterinya. Jika wanita tersebut telah menikahkan dirinya dengan suami yang tidak seimbang, wali mempunyai hak menolak dan melaporkan ke pengadilan untuk mem-fasakh (membatalkan) akad. Selain itu, hendaknya maharnya sebesar mahar mitsil atau kurang dari mahar mitsil jika walinya ridha. ${ }^{24}$

Perihal sebanding atau sepadan ini ditujukan untuk menjaga keselamatan dan kerukunan dalam pernikahan, bukan untuk kesahannya. Artinya sah atau tidaknya

${ }^{23}$ Abdul Aziz M. Azzam dan Abdul Wahhab Sayyed Hawwas, Fiqh Munakahat...., h. 96

${ }^{24}$ Abdul Aziz M. Azzam dan Abdul Wahhab Sayyed Hawwas, Fiqh Munakahat, ..... h.115 pernikahan tidak bergantung pada kafaah ini. Pernikahan tetap sah menurut hukum walaupun tidak sekafah antara suami istri. Hanya saja, hak bagi wali dan perempuan yang bersangkutan untuk mencari jodoh yang sepadan. Dengan arti, keduanya boleh membatalkan akad nikah dalam pernikahan itu karena tidak setuju dan boleh menggugurkan haknya.

Meskipun kafaah dalam segi harta, keturunan, keelokan paras (kecantikan dan ketampanan) bukan termasuk syarat, Rasulullah SAW, menganjurkan agar pasangan yang akan menikah hendaknya sepadan atau sekafaah. Kafaah ini tidak menjadi syarat dalam pernikahan. Akan tetapi, jika tidak ada keridaan masing-masing, salah satu pihak boleh membatalkan pernikahan itu dengan alasan tidak kafaah (setingkatan). Kafaah hanya berlaku dalam hal keagamaan, baik mengenai pokok agama seperti Islam dan bukan Islam, maupun kesempurnaannya. ${ }^{25}$

"Tidak sekufu tidak dapat dijadikan alasan untuk mencegah perkawinan, kecuali tidak sekufu karena perbedaan agama atau ikhtilafu al-din" ${ }^{26}$ Dalil yang digunakan para ulama fiqih dalam menentukan kesamaan agama sebagai kriteria pokok kafaah atau orang Islam yang kawin dengan orang yang bukan Islam, dianggap tidak sekufu.

\section{Metode Penelitian}

Metode penelitian yang digunakan dalam penelitian ini adalah pendekatan kualitatif. Pendekatan kualitatif adalah teknik pengumpulan data dengan menggunakan teknik gabungan. Analis data pada metode ini

\footnotetext{
${ }^{25}$ Beni Ahmad Saebani, Fikih Munakabat..., h. 122

${ }^{26}$ Tim, Komplikasi Hukum Islam (Bandung: Fukus Media, 2012), h. 23
} 
bersifat induktif, yaitu menganalis data dari umum ke khusus. ${ }^{27}$

Sementara, jenis penelitian yang digunakan adalah studi kasus, yaitu penelitian yang mendalam tentang individu, kelompok, organisasi, suatu program kegiatan dan sebagainya dalam waktu tertentu. Tujuannya adalah untuk memperoleh deskripsi yang utuh dan mendalam dari sebuah entitas. Studi Kasus menghasilkan data untuk selanjutnya dianalisa untuk menghasilkan teori. ${ }^{28}$

Teknik Pengumpulan Data yang digunakan dalam penelitian ini adalah : Observasi merupakan salah satu teknik pengumpulan data yang digunakan dalam penelitian kualitatif. ${ }^{29}$ Dengan observasi dapat kita peroleh gambaran yang lebih jelas tentang kehidupan sosial, yang sukar diperoleh dengan metode lain. ${ }^{30}$ Observasi adalah teknik pengumpulan data yang dilakukan melalui suatu pengamatan dengan disertai pencatatanpencatatan terhadap keadaan atau perilaku objek sasaran.

Wawancara adalah mengadakan komunikasi secara langsung dengan responden untuk mendapatkan data yang akurat, yaitu terhadap pihak-pihak yang terkait dalam penelitian ini. Wawancara atau interview adalah suatu bentuk komunikasi verbal, semacam percakapan yang bertujuan memperoleh informasi ${ }^{31}$. Pewawancara disebut Intervieuwer, sedangkan orang yang diwawancarai disebut Interviewee. Adapun bentuk pertanyaan yang penulis gunakan dalam wawancara ini adalah wawancara

${ }^{27}$ Rianto Adi, Metode Peneltian Sosial dan Hukum (Jakarta: Granit, 2005), h.57

${ }^{28}$ Lexy J.Moleong, Metodologi Penelitian Kualitatif (Bandung: PT Remaja Rosdakarya, 1995), h.75

29 Beni Ahmad Saebani, Metode Penelitian (Bandung: Pustaka Setia, 2008), h.186

${ }^{30}$ S. Nasution, Metode Research (Penelitian Ilmiab) (Jakarta: Bumi Aksara, 2007), h.106

${ }^{31} \mathrm{~S}$. Nasution, Metode Research (Penelitian Ilmiah) h. 113

Rahmat Pulungan terbuka yaitu wawancara yang menggunakan kuisioner terbuka (suatu teknik pengumpulan informasi yang mempelajari sikap-sikap, keyakinan, dan karakteristik beberapa orang). ${ }^{32}$

$\mathrm{Hal}$ ini dilakukan dengan cara mengajukan beberapa pertanyaan berbentuk lisan kepada informan dengan menggunakan alat bantu wawancara berupa pedoman wawancara atau daftar pertanyaan. Dalam hal ini wawancara penulis tujukan kepada masyarakat Melayu Kel. Bagan Batu, Kepala Lurah dan informan terkait lainnya. Hal yang akan diwawancarai seputar tradisi merasi dan dampak dari tradisi merasi tersebut setelah diadakannya perkawinan.

Informan adalah orang yang dimanfaatkan untuk memberikan informasi tentang situasi dan kondisi latar penelitian. Jadi ia mempunyai banyak pengalaman tentang latar penelitian. Ia berkewajiban secara suka rela menjadi tim penelitian, walaupun hanya bersifat informal. Sebagai anggota tim dengan kebaikannya dan kesukarelaannya, ia dapat memberikan pandangan tentang nilai-nilai, sikap, bangunan, proses dan kebudayaan yang menjadi latar penelitian setempat. ${ }^{33}$ Informan tersebut meliputi pemuka adat (datuk), orang yang telah melaksanakan merasi, kepala lurah, dan masyarakat setempat.

Dalam penelitian ini, penulis memusatkan penelitian di Kel. Bagan Batu Kec. Bagan Sinembah Kab. Rokan Hilir Prov. Riau. Kelurahan ini terletak pada perbatasan darat antara Provinsi Riau dan Sumatera Utara. Dengan demikian penulis ingin memberikan informasi terkait dengan tradisi merasi dalam penentuan kafaah.

${ }^{32} \mathrm{~S}$. Nasution, Metode Research (Penelitian Ilmiah) h. 113

33 Lexy J.Moleong, Metodologi Penelitian Kualitatif....., h. 90 


\section{Bagan Batu dan Sejarah Merasi}

Mula-mula yang datang membuka Kelurahan Bagan Batu adalah seorang datuk tua dan keluarganya. Datuk tersebut dikenal sebagai keturunan Kerajaan Melayu Kota Pinang Sumatra Utara yang bernama Datuk Said Ali Kasyim. Beliau berkedudukan penting di tahta Kerajaan Melayu Kota Pinang sebagai penasehat kerajaan. Awal mulanya, datuk dengan para temannya sering menjaring ikan di sungai wilayah Bagan Batu yang sekarang dinamai dengan sungai tembok berlin, karena hasil ikan yang cukup banyak para datuk dan teman-temannya terus menerus menjaring ikan disungai tersebut, sehingga menjadi rutinitas mereka dalam mengisi waktu luang. Dalam perjalanan ke sungai teresebut, datuk dan temannya harus menerjang semak belukar dan bebatuan besar yang ada di sepanjang jalan, bebatuan tersebut terbentuk dari tanah lihat yang mengering dan menyerupai bukit yang kecil.

Setelah Datuk Said Ali Kasyim melapas jabatan dari Kerajaan Melayu Kota Pinang, beliau beserta keluarga dan juga temantemannya memilih untuk menetap di perkarangan sungai tersebut. Kemudian masyarakat pun berkembang, banyak yang mulai tertarik dan memilih untuk menetap di kampung kediaman Datuk Said Ali Kasyim.

Nama Kelurahan Bagan Batu berasal dari kata-kata "bagan" yaitu Bahasa Melayu yang artinya tempat, tempat para datuk dan teman-temannya memancing ikan, tepatnya di sungai yang sekarang sudah dikelilingi sebuah tembok besar, disebut dengan tembok berlin. Dewasa ini, sungai tersebut tetap dirawat dan dijadikan sebagai kolam pelestarian ikan air tawar (ikan sungai).

Sedangkan kata “ batu” digunakan karena melihat keadaan wilayah Kelurahan Bagan Batu yang dahulunya dipenuhi dengan bebatuan besar yang membentuk bukit kecil, sehingga para penduduk yang ingin membangun rumah harus bekerja sama untuk membongkar atau memecahkan batu yang ada. $^{34}$

Merasi secara umumnya adalah salah satu proses untuk melihat keserasian dari pasangan atau menilik nasib para pasangan yang digunakan oleh orang Melayu dan masih ada yang mengamalkannya sampai sekarang. Walau bagaimanapun, kebanyakan orang Melayu tetap berpegang teguh terhadap adat ini, apa lagi masyarakat atau golongan yang termasuk dalam keturunan raja Melayu, mereka akan tetap menjunjung tinggi adat merasi. Adat merasi ini biasanya dilakukan untuk bakal pasangan yang ingin saling mengenal dan berkeinginan untuk melanjutkan hubungan mereka ke jenjang pernikahan.

Walaupun, dalam keadaan masyarakat sekarang yang boleh dikatakan agak bebas, seseorang itu boleh mengetahui perwatakan pasangan masing-masing melalui pertemuanpertemuan secara langsung dan tidak langsung. Keadaan ini secara tidak langsung membantu pasangan untuk mengetahui tentang keserasian diantara satu sama lain. Akan tetapi keperluan untuk merasi tetap timbul pada masyarakat Melayu zaman sekarang terkhususnya di Kel. Bagan Batu, sebagai proses adatyang bertujuan untuk penguat keserasian terhadap hubungan calon pasangan.

Praktek adat merasi dalam adat Melayu ini secara umum, boleh dikatakan tidak bertalian dengan derajat atau martabat seseorang atau satu-satu keluarga. Hal ini sesuai dengan pendapat Yohana bahwa adakalanya orang kaya, golongan bangsawan dan ternama masih mengamalkannya. Keadaan ini terjadi kerana orang yang mengamalkannya hidup dalam satu kelompok manusia yang eksklusif, yang dikelilingi oleh adat istiadat

${ }^{34}$ Maris, Wawancara Dengan Bapak Lurah Bagan Batu, 20 Juni 2015. 
kelompoknya sendiri dan adat tersebut dijaga dengan kokoh agar tidak lapuk ditelan zaman. Kebiasaan masyarakat seperti ini, sudah tergolong lama sejak awal leluhur Suku Melayu, kebiasaan merasi sudah diterapkan dan dijadikan salah satu proses dalam pernikahan masyarakat Melayu. Biasanya proses ini, mempunyai seorang datuk atau bomoh yang menjalankan adat merasi serta adat istiadat lainnya. ${ }^{35}$

Di Kelurahan Bagan Batu, adat merasi sudah dijalankan sejak mula masuknya masyarakat Melayu ke Bagan Batu, sekitar pada tahun 1960 dan berkembang pesat pada tahun 1981, sampai sekarang adat merasi tersebut masih berlaku bagi kalangan masyarakat Suku Melayu. Sedangkan masyarakat pendatang seperti: Suku Mandailing, Batak Toba, Hindu dan Budha, mereka menjalankan proses pernikahan sesuai dengan tradisi dan kepercayaan masingmasing. Jika masyarakat pendatang ingin menikah dengan perempuan atau laki-laki bersuku Melayu dan ingin melaksanakan pernikahan di tempat tinggal mereka Kel. Bagan Batu, mereka harus mengikuti proses adat Melayu yaitu merisik, merasi, hingga ke akad nikah. ${ }^{36}$

\section{Proses Merasi dalam Menentukan Kafaah di Kel. Bagan Batu}

Kegiatan merasi juga pernah disinggung dalam penelitian Dwijayanto untuk saat ini masih dijalankan oleh masyarakat Melayu Riau Bagan Batu. Karena pada arti sebenarnya, merasi adalah kegiatan menilik keserasian antara kedua calon pasangan yang dijodohkan.

35 Datuk. Nurdin, Wawancara Pribadi, Sabtu, 15 Juni 2015. Hal ini juga terdapat pada Yohana, Nova, and Kurnia Husmiwati, "Rules of Communication Interaction Basiacuang Oral Tradition in Traditional Marriage Malay Kampar Riau", Jurnal Penelitian Komunikasi, 18.1, 2015, h. 43.

${ }^{36}$ Gembira Siregar, Wawancara Pribadi dengan $R W$ 02 , Kamis, 18 Juni 2015
Kegiatan ini biasanya dilakukan oleh seorang perantara yaitu seorang ahli yang sudah biasa bertugas melakukan proses perjodohan ${ }^{37}$.

Pencari jodoh tersebut akan memberikan pendapatnya apakah pasangan yang dimaksud tersebut serasi atau tidak. Hal ini juga ditemukan dalam tradisi Nusantara lainnya seperti studi Widiana bahwa proses merasi yang dilakukan masyarakat Bagan Batu dengan cara menimbang ilmu keagamaan, pekerjaan, akhlak para calon pasangan dalam kehidupannya sehari-hari dan dilengkapi dengan proses penggabungan nama kedua calon pasangan ${ }^{38}$. Masyarakat Melayu dalam Faizah beranggapan bahwa proses ini sangat penting untuk dilakukan karena akan sangat mempengaruhi kehidupan rumah tangga calon pengantin dimasa depan agar tidak terjadi perceraian, musibah dan lain sebagainya ${ }^{39}$.

Proses merasi dilakukan sebelum dilaksanakannya peminangan, proses merasi ini dilakukan secara diam-diam oleh orang tua kedua belah pihak yang ingin menjodohkkan anaknya, agar diketahui keserasian pasangan tersebut. Di sebagian kalangan proses merasi disebut juga dengan proses falakiah, dan tatacara merasi yang dilakukan oleh seorang datuk disebut mem-fa'al. ${ }^{40}$

Setelah maksud meminang diterima, maka disepakatilah hari untuk pelaksanaan pinangan dengan mengantarkan tanda ikatan yang disaksikan oleh pemuka adat, keluarga, dan masyarakat setempat. Barang bawaan

37 Dwijayanto, Arik, "Migrasi, Adaptasi Dan Tradisi Komunitas Muslim Jawa Di Semenanjung Melayu", Dialogia, 15.2, 2015, h. 265-284.

38 Widiana, Nurhuda, "Pergumulan Islam Dengan Budaya Lokal Studi Kasus Masyarakat Samin di Dusun Jepang Bojonegoro", Jurnal Theologia, Vol. 26, No. 2, 2015, h. 65.

39 Faizah, Hasnah, "Nilai-Nilai Teks Cerita Panglimo Awang pada Tradisi Bukoba Masyarakat Melayu Pasir Pengairan", Bahasa, Sastra, dan Pembelajaran, 3.1, 2015, h. 134.

${ }^{40}$ Datuk. H. Ahmad Bilal, Wawancara Pribadi, Rabu, 24 Juni 2015 
berupa tepak, pinang, sirih, kapur sirih, gambir dan yang terpenting sepasang cincin sebagai simbolis ikatan pertunangan antara pasangan, hal inilah yang disebut dengan betukar cincin, sekaligus pemberian uang hantaran kepada pihak perempuan. ${ }^{41}$

Dalam proses peminangan ini, para keluarga kembali menghadap datuk dengan maksud untuk menetapkan hari, tanggal dan bulan yang baik untuk melaksanakan akad nikah (menata hari). Untuk menata hari biasanya dilakukan oleh datuk yang telah merasi kedua pasangan. Sebagaimana dalam Kamal, hal ini dilakukan untuk melihat tanggal dan hari yang sesuai untuk diselenggarakannya proses akad nikah (bijab qabub) ${ }^{42}$.

Umumnya, terlalu banyak cara-cara untuk merasi yang dilakukan para datuk, ada yang menanyakan hal kepribadian pasangan dari keseharian, ilmu agamanya, shalatnya, dan bacaan al-Qur'annya. Dalam hal menggabungkan nama para pasangan, ada yang mudah dan ada yang sukar disokong dengan petua-petua tertentu.

Dari hasil wawancara penulis dengan tiga datuk pemuka adat Melayu yang ada di Kel. Bagan Batu. Mereka sama-sama menyatakan bahwa proses merasi yang diperaktekkan selama ini tidak ada kaitannya dengan ilmu atau metode pembelajaran lainnya, melainkan hanya sebuah kepercayaan yang diwariskan secara turun temurun oleh leluhur mereka, yang bertujuan baik bagi keturunan mereka, hal ini dibuktikan dengan minimnya angka perceraian masyarakat Suku Melayu di Kel. Bagan Batu, setelah menjalani beberapa proses adat pernikahan Melayu diantaranya adalah proses merasi.

41 Datuk. H. Ahmad Bilal, Wawancara Pribadi, Rabu, 24 Juni 2015

${ }^{42}$ Kamal, Fahmi, "Perkawinan Adat Jawa Dalam Kebudayaan Indonesia", Khasanah Ilmu, 5.2, 2015, h. 65.

\section{Faktor Penyebab terjadinya TradisiMerasi dalam Penentuan Kafaah di Kel. Bagan Batu}

Terjadinya tradisi merasi terhadap pasangan yang akan bertunangan dalam penentuan kafaah disebabkan oleh beberapa faktor, sebagaimana yang dikemukakan oleh pemuka adat Kel. Bagan Batu melalui wawancara penulis antara lain:

Pertama, faktor tradisi masyarakat. Faktor tradisi merupakan salah satu faktor yang menyebabkan diharuskannya merasi sebelum pinangan dalam menentukan kafaah terhadap pasangan yang akan melaksanakan pernikahan. Bapak Sayuri selaku kepala RT 01 mengungkapkan bahwa sudah menjadi tradisi ditengah-tengah masyarakat Melayu melakukan merasi sebelum mereka bertunangan dan menikah.

Bagi yang tidak ingin merasi maka pasangan tersebut tidak diperbolehkan untuk menikah di Kel. Bagan Batu, mereka akan melaksanakan pernikahan dikampung halaman orang tuanya atau kampung tempat ia dilahirkan sebelum memasuki Kel. Bagan Batu dikarenakan mereka sudah dianggap orang yang meremehkan adat tradisi yang sudah dijunjung tinggi dan dipertahankan oleh masyarakat Melayu setempat. ${ }^{43}$

Andra mengungkapkan hal yang sama bahwa sudah menjadi tradisi proses merasi dilakukan terhadap pasangan yang akan menikah, tradisi ini sudah dijadikan adat turun temurun oleh leluhur mereka, apa lagi adanya pemangku adat yang menjaga upacara adat ini agar tetap dilestarikan dan dilaksanakan di tengah masyarakat Melayu Bagan Batu, maka adat ini menjadi tradisi sampai sekarang. ${ }^{44}$

Tradisi menjadi faktor tetap dilaksanakannya merasi dalam penentuan kafaah

43 Sayuri, Bapak RT 01, Wawancara Pribadi, Rabu, 10 Juni 2015.

44 Andra, Pelaksana Proses Merasi, wawancara pribadi, Rabu, 10 Juni 2015. 
bagi pasangan yang hendak bertunangan, tradisi ini sudah berlangsung sejak lama, bahkan sebelum Bagan Batu ini menjadi Kelurahan, seluruh masyarakat Melayu disini sudah melaksanakan merasi sebagai salah satu upacara adat perkawinan mereka.

Kedua, faktor pendidikan pasangan. Pendidikan merupakan kebutuhan dasar dan usaha dasar untuk menyiapkan peserta didik melalui kegiatan bimbingan dan juga sarana untuk mendapatkan kebahagian. ${ }^{45}$ Dalam Mawardi, dengan adanya pendidikan orang akan memiliki ilmu pengetahuan dan berpengaruh juga terhadap prilaku serta kebijakan untuk menjalani kehidupan rumah tangga atau mewujudkan keluarga bahagia. ${ }^{46}$

Berdasarkan hasil observasi penulis lakukan dan juga wawancara yang telah dilakukan terhadap beberapa orang tokoh, salah satu alasan diharuskannya merasi pada pasangan yang hendak menikah disebabkan faktor pendidikan, maksudnya adalah laki-laki maupun perempuan tersebut tidak mempunyai pendidikan tinggi, hanya tamatan SD dan SMP sehingga mereka tidak mempunyai gambaran masa depan dalam rumah tangga. Walaupun mereka mempunyai pendidikan tinggi masih dikhawatirkan belum bisa menentukan kafaah diantara mereka berdua dan apabila dibiarkan begitu saja dikhawatirkan akan berujung dengan ketidak rukunan rumah tangga dan perceraian.

Banyak dari pasangan hanya memodalkan keinginan dan semangat belaka ataupun emosional sehingga tidak bisa merumuskan gambaran membangun rumah tangga, apakah terkait masa depan biaya hidup serta resiko terhadap hubungan keluarga kedua

45 Hasbullah, Otonomi Pendidikan, (Jakarta: Raja Grafindo Persada, 2006), h. 45

${ }^{46}$ Edi Rosman, Sosiologi Keluarga Islam (STAIN: Press Bukittinggi), h. 186. Juga terdapat pada Mawardi, Marmiati, "Problematika Perkawinan di Bawah Umur", Jurnal Analisa, 19.02, 2010, h. 126. belah pihak, bila pasangan tersebut dibiarkan menikah begitu saja tanpa merasi terlebih dahulu, maka kondisi yang buruk akan selalu menimpa keluarga mereka kelak, itulah sebabnya diadakan merasi untuk menilik dan mengetahui gambaran masa depan mereka setelah menikah. ${ }^{47}$

Dan pendidikan juga sangat diperlukan dalam kehidupan, serta masih ada juga orang tua sangat mengekang anaknya sehingga perbedaan jenjang pendidikan menjadi standar untuk melaksanakan perkawinan. ${ }^{48}$

Ketiga, faktor lemahnya ilmu keagamaan pasangan. Keagamaan adalah ajaran yang mengatur kepercayaan, peribadatan kepada Tuhan Yang Maha Esa dan cara berhubungan sesama manusia dan makhluk lainnya ataupun sesuatu mengenai agama. faktor agama ini juga sangat berpengaruh kepada pihak yang melakukan pernikahan, karena agama dasar terpenting dalam membangun rumah tangga.

Berdasarkan hasil wawancara yang penulis lakukan terhadap salah datuk di RW 02 Kel. Bagan Batu, diharuskannya merasi ini karena faktor lemahnya ilmu keagamaan pasangan yang hendak menikah, maksudnya sebagian laki-laki sabagai calon suaminya tidak mempunyai dasar-dasar agama, seperti: membaca al-Qur'an, tidak melaksanakan shalat dan tidak mau bergaul dengan masyarakat sehingga dapat berpengaruh terhadap perkawinan yang dilakukan.

Sebelum merasi para datuk akan menanyakan kepada kedua orang tua pihak yang akan di-merasi, terkait dengan ilmu agama anak mereka, apakah mereka bisa shalat dan mengaji, setelah itu barulah datuk memulai merasi nama para calon pengantin. Hal ini ditanyakan oleh datuk karena pengetahuan agama juga menjadi pertimbangan untuk

${ }^{47}$ Datuk Nuruddin, Wawancara Pribadi, Minggu, 21 Juni 2015

${ }^{48}$ Edi Rosman, Sosiologi Keluarga Islam....., h. 186 
menentukan keserasian dari para pasangan di samping hasil dari proses merasi. ${ }^{49}$

\section{Analisis Tradisi Merasi dalam Penentuan Kafaah di Kel. Bagan Batu}

Kebutuhan hidup manusia mengalami perkembangan dari waktu ke waktu, yang dalam hal ini sejalan dengan perobahan pola fikir manusia serta budaya yang berkembang ditengah-tengah masyarakat, mulai dari masyarakat yang nomaden primitif sampai pada masyarakat modern dan metropolis, yang secara langsung atau tidak langsung menggeser emosi dan prinsip individu manusia dalam memikirkan kebutuhan dan kelangsungan hidupnya ${ }^{50}$.

Hal ini mengalami hambatan ketika berhadapan dengan prinsip-prinsip agama Islam yang nota benenya adalah mengayomi umatnya. Sebagai akibat dari perkembangan zaman tersebut membuat manusia berhati-hati dalam mengambil setiap tindakan untuk kepentingan manusia itu sendiri. Yang mana hal ini juga berimbas kepada cita-cita kehidupan rumah tangga yang bertujuan untuk melanjutkan keturunan, kehati-hatian itu menunjukkan bahwa pernikahan merupakan satu-satunya jalan untuk membina keluarga yang di-ridhai oleh Allah SWT.

Salah satu bukti dari kehati-hatian manusia adalah ketika akan melangsungkan pernikahan yaitu dengan memilih dan melihat siapa yang akan menjadi pasangan hidupnya, apakah orang yang akan menjadi pasangan hidupnya se-kufu dengannya atau tidak. Dalam al-Qur'an telah dianjurkan juga agar menikahi orang-orang yang layak (sekufu) untuk dijadikan pasangan hidup, baik itu dari

\footnotetext{
${ }^{50}$ Rozi, Syafwan, "Konstruksi Identitas Agama dan Budaya Etnis Minangkabau di Daerah Perbatasan: Perubahan Identitas dalam Interaksi Antaretnis di Rao Kabupaten Pasaman Sumatera Barat", Masyarakat Indonesia, 39.1, 2013, h. 215-245.
}

${ }^{49}$ Datuk Nuruddin, Wawancara Pribadi, Minggu, 21 Juni 2015 golongan hamba sahaya laki-laki maupun perempuan.

Anjuran untuk menikahi pasangan yang sekufu juga dijelaskan oleh Nabi SAW :

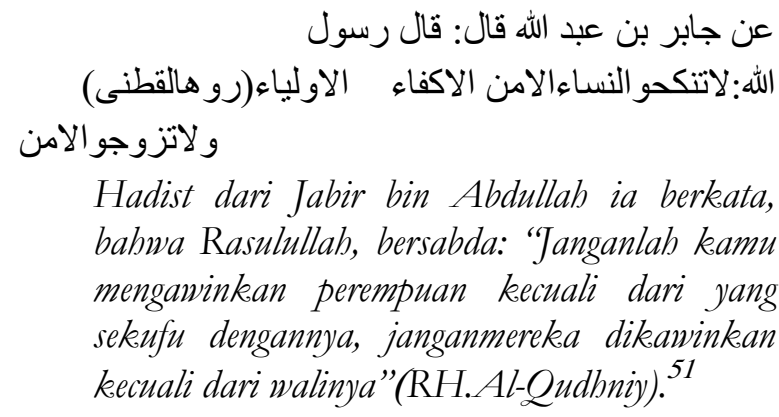

Proses mencari dan menetapkan kafaah di antara pasangan, di kalangan ulama dan setiap masyarakat mempunyai kriteria dan cara masing-masing untuk menentukannya. Dalam fikih klasik, di antaranya pendapat golongan Syafi'i yang memandang ukuran kafaah bukan saja agama tapi ada unsur-unsur lain yang harus dipenuhi seperti, nasab (keturunan), pekerjaan, dan merdeka. Jika hal tersebut dituntut untuk dipenuhi dalam menentukan kafaah antara pasangan, maka masyarakat akan sulit menerimanya, karena masyarakat terdiri dari berbagai suku dan golongan, yang setiap suku dan golongan tersebut mempunyai pandangan yang berbeda tentang kemuliaan seseorang.

Sebagai contoh di daerah Melayu Riau, keturunan datuk dipandang mulia bila dibandingkan dengan keturunan yang lain, begitu juga di daerah Jawa, yang dikenal dengan keturunan darah biru (keraton) akan dipandang mulia dan dihormati dibandingkan dengan yang lain, masing-masing suku dan golongan itu pasti fanatik dengan kesukuan dan keturunannya, karena itu sudah menjadi kodrat bagi manusia.

Oleh karena itu dalam hal se-kufu Kompilasi Hukum Islam memandang sekufunya seseorang adalah sama dari segi

51 Imam Hafiz bin Umar, Sunan Addar Quthni, (Beirut: Liban, t, th), jilid III, h. 173 
agamanya dengan menjadikan agama sebagai ukuran dari kafaah seseorang merupakan pengambilan langkah hukum yang sangat tepat, mengingat dan menimbang di Indonesia berkembang bermacam agama, karena masyarakat Indonesia adalah masyarakat yang majemuk, kemejumukannya juga terletak pada keyakinan dan agama. Disamping itu ada aliran kepercayaan yang bersumber bukan pada ajaran agama tetapi bersumber pada keyakinan tumbuh dikalangan masyarakat itu sendiri, yang oleh kepemerintahan digolongkan pada kepercayaan yang merupakan bahagian dari tradisi dan kebudayaan.

Setiap masyarakat pasti mempunyai tradisi atau kebudayaan yang mereka junjung tinggi, seperti kalangan masyarakat Melayu Riau di Kelurahan Bagan Batu, tradisi merasi merupakan tradisi yang terus dilakukan secara kontuniu dalam penentuan kafaah. Selain melihat standar kafaah dalam fikih klasik dari berbagai mazhab serta kafaah menurut KHI, mereka juga menjalankan upacara merasi untuk melengkapinya.

Bukan hanya kepemerintahan saja yang membicarakan dan mengesahkan tradisi seperti ini, yang disebut dengan tradisi atau budaya. Dalam fikih tradisi seperti ini juga dibicarakan dalam pembahasan 'Urf. U'rf secara harfiyah adalah suatu keadaan, ucapan, perbuatan atau ketentuan yang telah dikenal manusia dan telah menjadi tradisi untuk melaksanakannya atau meninggalkannya. Di kalangan masyarakat urfi ini sering disebut juga dengantradisi atau adat. ${ }^{52}$

Hasil wawancara penulis dengan masyarakat Kelurahan Bagan Batu secara umum tentang apakah manfaat dari merasi. Menurut pendapat para informan, bahwa merasi itu memang harus dilakukan karena sebagian masyarakat yang akan menikah tidak

${ }^{52}$ Rachmat Syafe'i, Imu Ushul Fiqih (Bandung: CV Pustaka Setia, 1998), h.129. mengetahui bagaimana kepantasan dirinya dengan calonnya, dan mereka tidak tahu pasti ada atau tidaknya larangan atau perintah merasi ini di dalam syari'at Islam, akan tetapi menurut para informan tujuan dari merasi ini adalah mencari keserasian antara kedua pihak pengantin, dan itu sah-sah saja. ${ }^{53}$

Proses merasi ini, sudah menjadi tradisi pernikahan Suku Melayu di Bagan Batu, yang diterima oleh kalangan masyarakat, dipatuhi, bahkan dijaga agar tetap dijalankan sebagai salah satu proses adat pernikahan.

Pada dasarnya masyarakat Melayu Bagan Batu mengetahui bahwa tidak ada ketentuan atau ajaran tentang merasi dalam syri'at Islam dilihat dari kitab fikih yang ada, tetapi mereka tidak bisa berbuat lain karena merasi sudah menjadi tradisi atau tradisi di wilayah ini dari dulu sampai sekarang serta di waktu yang akan datang. Mereka hanya berkeyakinan bahwa segala sesuatu yang baik dimata manusia dan tidak bertentangan dengan syar'iat Islam, akan baik dan diterima oleh Allah SWT.

Dari uraian di atas penulis berpendapat bahwa proses merasi ini termasuk dalam katagori 'urf dalam ilmu fikih dan tergolong pada 'urffi'ly yaitu adat atau tradisi yang dikerjakan secara berulang-ulang dengan perbuatan.

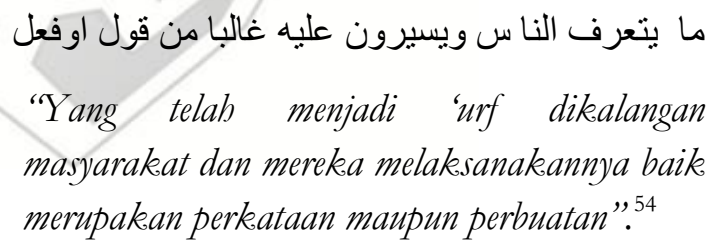

Dari hasil wawancara yang penulis lakukan terhadap tujuh orang pelaksana merasi dan tiga orang datuk, mereka mengakui bahwa proses merasi dilakukan demi kemaslahatan para calon pengantin yang akan bertunangan agar mereka tidak menyesal dikemudian hari, 2015.

${ }^{53}$ Yurneni, Wawancara Pribadi, Minggu, 28 Juni

${ }^{54}$ Hasbi Ash. Shiddieqy, Sari Kuliah Ushul Fiqih (Yogyakarta: CV Ramadhan Sala, 1972), h. 34. 
setelah diadakannya merasi para pasangan dapat mengambil gambaran dan dijadikan sebuah bahan pertimbangan untuk tetap melanjutkan atau mengakhiri hubungan mereka. Dampak positif yang didapatkan para kedua belah pihak lebih besar dari proses merasi ini, dibandingkan dengan hal negatifnya hanya ada sebagian kecil.

Penerimaan 'urf atau adat tradisi itu adalah 'urf atau adat tradisi yang akan membawa kemashlahatan dan urf atau adat tradisi itu telah terkenal dalam masyarakat dan dipandang baik. ${ }^{55}$

'Urf terdiri dari dua macam yaitu "urf shabih dan urf fasid. 'Urf shabih yaitu sesuatu yang telah saling kenal oleh manusia dan tidak bertentangan dengan dalil syara', tidak menghalalkan yang haram dan juga tidak membatalkan yang wajib. Adapun 'urf fasid yaitu sesuatu yang telah saling kenal oleh manusia tetapi bertentangan dengan syara', atau menghalalkan yang haram dan membatalkan yang wajib. ${ }^{56}$

Sepanjang ini menurut para datuk, proses merasi tidak bertentangan dengan agama karena mereka hanya menguatkan standar kafaah setelah diperhatikannya hal-hal yang menjadi penilaian kafaah di dalam ilmu fikih. Proses merasi juga tidak pernah menghalalkan hal yang haram dalam perakteknya, apalagi sampai membatalkan hal yang wajib.

Tradisi merasi juga sejalan dengan alasanalasan dan syarat-syarat dari para ulama dalam pemakaian 'urf, antara lain; Pertama, 'urf tidak boleh dipakai untuk hal-hal yang akan menyalahi nash yang ada; Kedua, 'urf tidak boleh dipakai apabila mengesampingkan kepentingan umum. Ketiga, urf tidak bisa

${ }^{55}$ Asymuni A. Rahman, Kedudukan Adat Kebiasaan (Urf) Dalam Hukum Islam (Yogyakarta: CV Bina Usaha, 1983), h. 12.

${ }^{56}$ Rachmat Syafe'i, Ilmu Ushul Fiqih,..... h. 129. dipakai apabila membawa kepada keburukankeburukan atau kerusakan. ${ }^{57}$

\section{Kesimpulan}

Proses merasi yang dilakukan masyarakat Bagan Batu yaitu dengan cara menggabungkan kedua nama calon mempelai oleh seorang datuk. Kemudian datuk meramal keadaan rumah tangga mereka nantinya setelah menikah. Cara merasi ini beragam metodenya sesuai dengan datuk yang akan mem-faal.

Kafaah dalam hukum Islam bisa tidak diperhatikan jika berbagai pihak rela dengan kondisi orang yang akan menjadi calonnya, namun dalam adat Melayu Bagan Batu perkawinan tersebut dilarang dengan dilakukannya proses merasi, karena bertujuan untuk mengurangi kemudharatan dan demi tercapainya kemaslahatan dalam pernikahan.

Tradisi merasi dalam penentuan kafaah yang terjadi di Kel. Bagan Batu boleh diterima dan diberlakukan, karena tidak bertentangan dengan hukum Islam yang juga menginginkan kemaslahatan umat dan tergolong dalam u'rf shabih.

Setelah penulis melakukan penelitian dan memperoleh hasilnya, maka penulis akan memberikan sedikit saran kepada beberapa pihak yang terkait dengan aturan ini umumnya kepada masyarakat di Kelurahan Bagan Batu selaku orang-orang yang diberi kewajiban secara adat untuk melaksanakannya; 1) Kepada masyarakat agar lebih mencintai, menghargai dan mematuhi aturan adat yang sudah ditetapkan selama aturan tersebut tidak bertentangan dengan ajaran Islam atau memiliki tujuan untuk kebaikan terhadap seluruh masyarakat dibawah naungan aturan adat; 2) Diharapkan kepada orang tua, khususnya para pemuka adat di Kelurahan Bagan Batu untuk dapat menyumbangkan

57 A. Basiq Djalil, Ilmu Ushul Fiqih (Jakarta: Kencana, 2010), h.163 
buah pikirannya dan ilmunya kepada warga masyarakat tentang masalah adat, khususnya tentang tujuan tradisi merasi dalam penentuan kafaab; 3) Kepada para pemuda selaku kaum yang berpotensi untuk dikenakan aturan, agar menyadari pentingnya dan menjalankan aturan adat dengan penuh kesadaran karena aturan ini bagian dari kekayaan adat masyarakat Kelurahan Bagan Batu, yang memiliki tatanan adat yang tersusun rapi; dan, 4) Kepada para datuk, alim ulama dan cadiak pandai dalam menetapkan hukum, harus mempertimbangkan kemaslahatan dengan baik, agar tidak merugikan masyarakat setempat dan harus memberikan efek jera terhadap pelaku.

\section{Daftar Pustaka}

\section{Buku Teks}

Abu Luwis, al-Ma'luf, Munjid (Beirut: Maktabah al-Katulikiyah Babil Halabi, 1997).

Adhim Muhammad Fauzil dan M. Nazif Mansyur, Di Ambang Pernikahan (Jakarta: Gema Insani Pers, 2002).

An-Nasai, Imam Abi Husain Muslim bin Hajjaj Al-Qusyairi, Shabiah Muslim, (Indonesia: $\mathrm{t}$, th)

Azzam, Abdul Aziz M. dan Abdul Wahhab Sayyed Hawwas, Figh Munakahat (Jakarta: Amzah, 2009).

Djalil, A. Basiq, Ilmu Ushul Fiqih (Jakarta: Kencana, 2010).

Fuad, Kauma dan Nipan, Membingbing Isteri Mendampingi Suami (Yogyakarta: Mitra Pustaka, 2003).

Ghazaly, Abdur Rahman, Fiqh Munakahat ( Jakarta: PT Grafindo Persada, 2003).

Hasbullah, Otonomi Pendidikan (Jakarta: Raja Grafindo Persada, 2006).

Idhami, Dahlan, Azas-Azas Fiqib Munakahat (Surabaya: Al-Ikhlas, 1991).
Lexy J.Moleong, Metodologi Penelitian Kualitatif (Bandung: PT Remaja Rosdakarya, 1995).

Lubis, Salam, Menuju Keluarga Sakinah (Surabaya: Salam, 2003).

Mahdi, Mahmud, Kelurga Sakinah (Jakarta: PT Sahara, 2013).

Moleong, Lexy J., Metodologi Penelitian Kualitatif. (Bandung: PT Remaja Rosdakarya, 1995).

Mustofa Hasan, Pengantar Hukum Keluarga (Bandung: CV Pustaka Setia, 2011).

Nasution S., Metode Research (Penelitian Ilmiah) (Jakarta: Bumi Aksara, 2007).

Rahman, Asymuni A., Keduduka Adat Kebiasaan (Urf) Dalam Hukum Islam (Yogyakarta: CV Bina Usaha, 1983).

Rianto, Adi, Metode Peneltian Sosial dan Hukum (Jakarta: Granit, 2005).

Rosman, Edi, Sosiologi Keluarga Islam (Bukittinggi: STAIN Press Bukittinggi, 2016)

Rusyadi, Kamus Arab-Indonesia (Jakarta: Bineka Cipta, 1995).

Saebani, Beni Ahmad, Fiqh Munakahat 2 (Bandung : Pustaka Setia, 2001).

Sahrani, Tihami dan Sohari, Fikih Munakahat (Jakarta: Raja Wali Pres, 2010).

Shiddieqy, Hasbi Ash., Sari Kuliah Ushul Fiqib (Yogyakarta: CV Ramadhan Sala, 1972).

Syafe'i, Rachmat, Ilmu Ushul Fiqih (Bandung: CV Pustaka Setia, 1998).

Syarifuddin, Amir, Hukum Perkawinan Islam di Indonesia (Jakarta: kencana, 2007).

Tim, Komplikasi Hukum Islam (Bandung: Fukus Media, 2012).

Umar, Imam Hafiz bin, Sunan Addar Quthni (Bairut: Liban t, th).

\section{Jurnal}

Dwijayanto, Arik, "Migrasi, Adaptasi dan Tradisi Komunitas Muslim Jawa di 
Semenanjung Melayu", Dialogia, 15.2, 2015.

Faizah, Hasnah, "Nilai-Nilai Teks Cerita Panglimo Awang pada Tradisi "Bukoba" Masyarakat Melayu Pasir Pengairan", Babasa, Sastra, dan Pembelajaran, 3.1, 2015.

Fatimah, Rezki Puteri Syahrani Nurul, "Tunjuk Ajar Melayu dalam Pantun Adat Perkawinan Melayudi Kelurahan Daik, Kabupaten Lingga, Provinsi Kepulauan Riau", Jurnal Bahas, 10.2, 2015.

Kamal, Fahmi, "Perkawinan Adat Jawa dalam Kebudayaan Indonesia", Khasanah Ilmu, 5.2, 2015.

Mawardi, Marmiati, "Problematika Perkawinan di Bawah Umur", Jurnal Analisa, 19.02, 2007

Muslim, Muslihun, and Muhammad Taisir, "Tradisi Merari': Analisis Hukum Islam dan Gender terhadap Adat Perkawinan Sasak", Yogyakarta: Kurnia Kalam Semesta, Vol. 12, No. 2, 2009.

Novia, Nila, and Swis Tantoro, "Perubahan Adat Perkawinan Suku Sakai di Pemukiman Buluh Kasap Kopelapip Kecamatan Mandau", Jurnal Online Mahasiswa (JOM) Bidang Ilmu Sosial dan Ilmu Politik, 1.1, 2014.

Rachmadani, Arnis, "Local Wisdom Tradisi Perkawinan Islam Wetu Telu sebagai Perekat Kerukunan Masyarakat Bayan", Dinamika Beragama dalam Pergumulan Sosial Budaya, Vol. 1 No. 2, 2015.

Riva'ie, Wanto, and Gusti Budjang, "Peran Tokoh Masyarakat Menanamkan Nilainilai Solidaritas dalam Tahapan Pesta Perkawinan Suku Melayu", Jurnal Pendidikan dan Pembelajaran, 5.06, 2015.

Rozi, Syafwan, "Konstruksi Identitas Agama dan Budaya Etnis Minangkabau di Daerah Perbatasan: Perubahan Identitas dalam Interaksi Antaretnis di Rao
Kabupaten Pasaman Sumatera Barat", Masyarakat Indonesia, 39.1, 2013

Sobirin, Achmad, "Merger dan Akuisisi: Sebuah Perkawinan Paradoksal", Jurnal Siasat Bisnis, 1.6, 2001.

Widiana, Nurhuda, "Pergumulan Islam Dengan Budaya Lokal Studi Kasus Masyarakat Samin di Dusun Jepang Bojonegoro", Jurnal Theologia, Vol. 26, No. 2, 2015.

Yohana, Nova, and Kurnia Husmiwati, "Rules of Communication Interaction Basiacuang Oral Tradition in Traditional Marriage Malay Kampar Riau", Jurnal Penelitian Komunikasi, 18.1, 2015.

\section{Wawancara}

Maris, Hasil Wawancara, 20 Juni 2015.

Andra, Pelaksana Proses Merasi, Wawancara Pribadi, Rabu, 10 Juni 2015.

Datuk. H. Ahmad Bilal, Wawancara Pribadi, Rabu, 24 Juni 2015.

Datuk. Nurdiin, Hasil Wawancara Pribadi, Sabtu, 15 Juni 2015

Gembira Siregar, Hasil Wawancara Pribadi, Kamis, 18 Juni 2015

Sayuri , Bapak RT 01, Wawancara Pribadi, Rabu, 10 Juni 2015

Yurneni, Wawancara Pribadi, Minggu, 28 Juni2015. 